\title{
IMPLICATIONS OF MAJOR ELEMENT COMPOSITION FOR THE MANTLE SOURCES OF KIMBERLITE, AILLIKITE, OLIVINE LAMPROIITE, AND MEIMECHITE
}

\author{
Don Francis \\ Earth \& Planetary Sciences, McGill University, Canada
}

\section{INTRODUCTION}

The alkaline ultramafic dykes known to host diamonds share the unusual compositional characteristic of being highly enriched in incompatible trace elements, but highly refractory in terms of major elements. Despite their mineralogical diversity, however, taken together they constitute a compositional extreme in the array from Archean komatiites to ferropicrites (Fig. 1) and may represent an important mantle component(s), possibly analogous to lunar "KREEP" (Anderson, 1989), in the mantle source regions of many basalts.

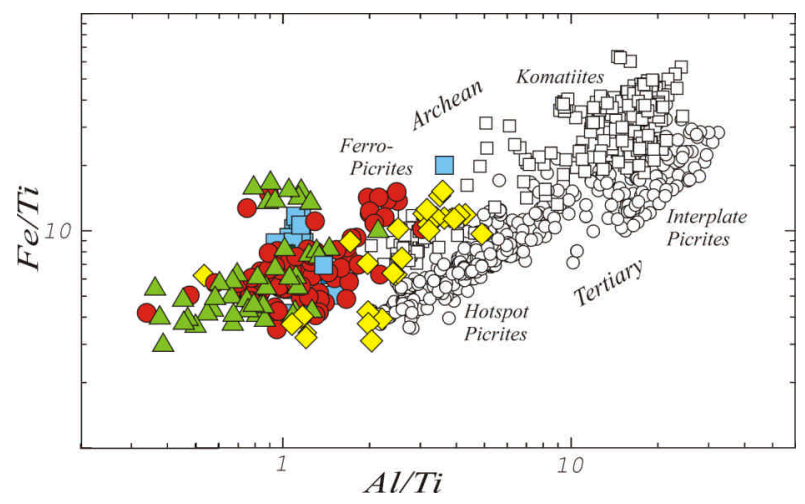

Figure 1: $\mathrm{Al} / \mathrm{Ti}$ versus $\mathrm{Fe} / \mathrm{Ti}$ by wt. for group-I kimberlites (red circle), group-II kimberlites and olivine lamproites (yellow diamond), aillikites (green triangle), meimechites (blue square), all with greater than $15 \mathrm{wt} . \% \mathrm{MgO}$, along with Archean komatiites and ferropicrites (gray square), Tertiary picrites (open circle) with greater than 12 wt.\% MgO. Data sources: Arndt, et al., 1995, Baragar, et al., 2001, Bourne and Bossé, 1991, Digonnet, et al., 2000, Edwards, et al., 1992, Francis, 1995, Fraser and Hawkesworth, 1992, Jaques, et al., 1984, LeRoex, et al., 2003, Price, et al., 2000, Schmidberger and Francis, 2001, Scott, 1979, Scott Smith, et al., 1996, Taylor, et al., 1994.

Until recently, sampling problems have limited our knowledge of the major element compositions of the magmas responsible for these rocks. A survey of recent chemical analyses of hypabyssal-facies alkaline ultramafic rocks, however, suggests they can be reliably distinguished on the basis of their $\mathrm{Si}$ and Fe contents in a standard whole rock chemical analysis. Furthermore, the major element differences between the alkaline ultramafic magma types have important implications not only their genetic inter-relationship, but also for the nature of mantle source regions and possibly the diamond potential of kimberlites.

\section{DATA}

The alkaline ultramafic rock known to host diamonds include both group-I and group-II kimberlites (orangeites), olivine lamproites, as well as ultramafic lamprophyres, such as aillikites, and possibly meimechites. The nomenclature, classification, and thus petrogenesis, of these alkaline ultramafic rocks are a confusing legacy of a time when modern analytical techniques were not available and formal classification was based upon mineralogy, or even geography. This situation is exacerbated by the problems of heteromorphism and incomplete reactions associated with the volatile-dependent stabilities of phases such as phlogopite, which in some cases leads to rocks with identical chemical compositions having different names (Yoder, 1986) . To make matters worse, the common fragmental nature of these rocks, especially where they occur as diatreme breccias with clastic matrices or tuffaceous volcanics, along with the abundance of accidental fragments of both the crust and mantle, as well as susceptibility to weathering and serpentinization, have discouraged studies of their whole rock compositions. As a result, the classification of any given occurrence remains a rather esoteric process, often best left to experts.

With the deeper exploitation of South African mines, and more recent finds in Arctic environments, however, there have now appeared a number of studies of finegrained hyabyssal dyke facies of many of these different rock types. The dataset examined here 
consists of a collection of such analyses, filtered for $\mathrm{MgO}$ greater than $15 \mathrm{wt} . \%$. One of the most striking features of the dataset is the presence of a distinct population minimum in terms of $\mathrm{Si}$ that coincides with the olivine - phlogopite compositional join (Fig. 2). Both aillikites and group-I kimberlites have very low $\mathrm{Si}$ contents that fall to the Si-poor side of the olivine phlogopite join (Fig. 2). This means that they lie outside the space that can be expressed in terms of the compositions of mantle silicates alone, requiring the presence of carbonate(s) in these rocks. This can be seen in the anti-correlation between $\mathrm{C}$ and $\mathrm{Si}$ in type-I kimberlites and aillikites, which plot along the olivine carbonate join (Fig. 3).

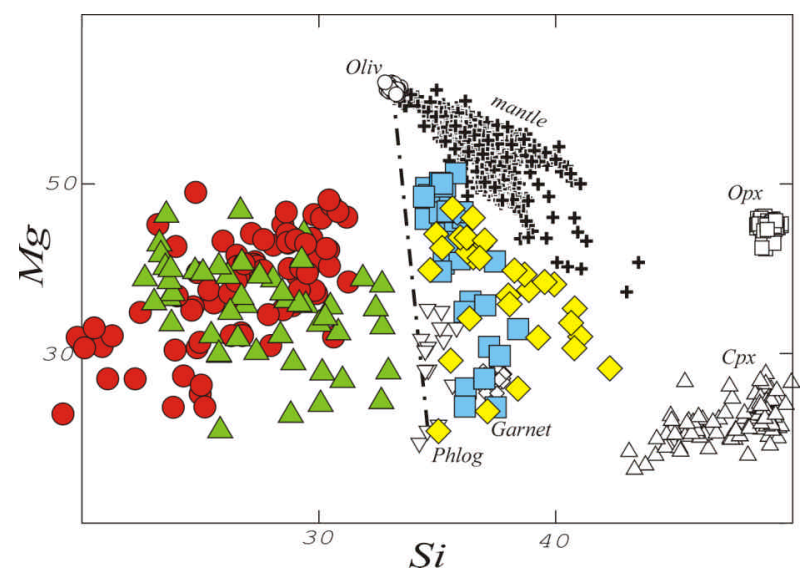

Figure 2: $\mathrm{Si}$ versus $\mathrm{Mg}$ in cation units (including C). Mantle xenoliths (black cross), olivine (open circle), phlogopite (open inverted triangle), garnet (open diamond), clinopyroxene (open triangle), orthopyroxene (open square). Other symbols as in Fig. 1.

The fractionation of the olivine and phlogopite phenocrysts that characterize of many of these rocks would lead to more Si-poor, but carbonate-rich residual liquids, with decreasing $\mathrm{Mg}$. This is apparent in the data for the group-I kimberlites in which $\mathrm{Ca}$ increases as $\mathrm{Mg}$ and $\mathrm{Si}$ decrease along the olivine - calcite join (Fig. 3). Unlike the group-I kimberlites, however, Si appears to increase and carbonate decrease with decreasing $\mathrm{Mg}$ in the aillikites. The most magnesian aillikites are lower in $\mathrm{Si}$ and richer in carbonate (typically dolomite) than group-I kimberlites with equivalent $\mathrm{Mg}$ (Fig. 2 \& 3), but at lower $\mathrm{Mg}$ aillikites are more Si-rich and carbonate-poor than most group-I kimberlites. Similarly, although high-Mg aillikites have $\mathrm{Ca}$ contents that overlap those of group-I kimberlites, they trend away from the dolomite olivine join as opposed to towards calcite (Fig. 3), as is the case for the group-I kimberlites. Although these trends in the global aillikite dataset are somewhat diffuse, they persist within single suites of aillikite dykes, such as those along the west coast of Greenland.

The more micaceous group II kimberlites (orangeites) and olivine lamproites, as well as meimechites, fall to the Si-rich side of the olivine - phlogopite join, such that their compositions can be expressed in terms of mantle silicates alone, with no requirement for carbonate (Figs. 2). In contrast to the group-I kimberlites, group-II kimberlites and olivine lamproites would evolve towards more Si-rich residual liquids with decreasing $\mathrm{Mg}$ via the fractionation of olivine and/or phlogopite, consistent with the common association of olivine lamproites with even more Si-rich lamproite derivatives. Unlike the case in the group-I kimberlites, $\mathrm{Ca}$ remains roughly constant with decreasing $\mathrm{Mg}$ and increasing $\mathrm{Si}$ from the group-II kimberlites to olivine lamproites (Fig. 3), implying the involvement a Ca-rich phase, such as clinopyroxene. In contrast, the increase in $\mathrm{Si}$ and $\mathrm{Ca}$ with decreasing $\mathrm{Mg}$ in the meimechites is consistent with the fractionation of olivine alone (Fig. $2 \& 3$ ).

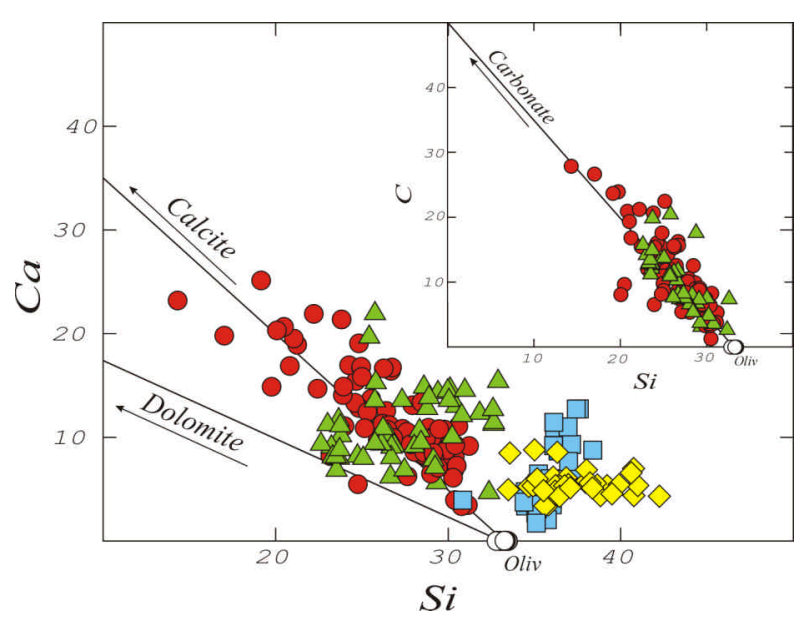

Figure $3 \mathrm{Ca}$ and $\mathrm{C}$ (insert) versus $\mathrm{Si}$ in cation units. Symbols as in Fig. 2.

There are striking differences in Fe on both sides of the olivine-phlogopite divide. On the Si-poor side there appears to be a gradation from the low $\mathrm{Fe}$ contents of classical group-I kimberlite suites $(\mathrm{FeO}<11$ wt.\%) through transitional kimberlite suites to Fe-rich aillikites $(\mathrm{FeO}>12 \mathrm{wt} . \%)$, with little regard for $\mathrm{Mg}$ (Fig. 4). A similar range in Fe content exists on the $\mathrm{Si}$ rich side of the olivine - phlogopite join. Group-II kimberlites and olivine lamproites appear constitute a continuous array of decreasing $\mathrm{Mg}$ with slightly 
increasing, but low $\mathrm{Fe}$, whereas a similar array for meimechites is shifted to distinctly more Fe-rich compositions, which overlap those of the aillikites.

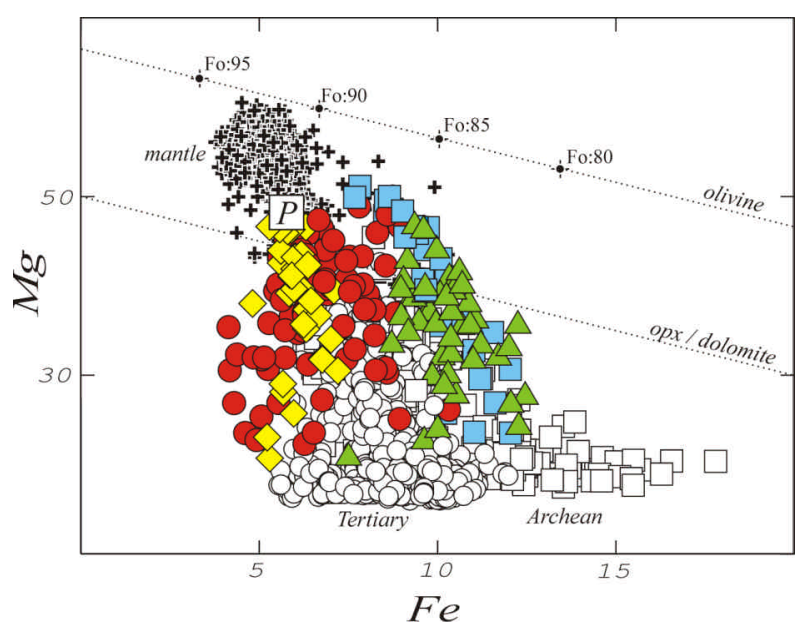

Figure 4: Fe versus $\mathrm{Mg}$ in cation units. Symbols as in Figs. $1,2 \& 3$.

\section{DISCUSSION}

The coincidence of a population minimum in the alkaline ultramafic rock dataset with the olivine phlogopite join, and the common present of these phases as phenocrysts in these rocks, suggest that this join represents a thermal divide or alkemade line that provides a convenient criteria for distinguishing between group-I and group-II kimberlites. The origin of the population minimum may reflect the tendency of residual liquids on either side of the join to move away by the fractionation of olivine and phlogopite on route to the surface. Furthermore, it is possible that the olivine - phlogopite join separates two distinct parental liquids, one to the Si-poor side of the join produced by melting in a carbonate - bearing system, and the other to the Si-rich side for melting in a phlogopite-bearing system.

Although the average aillikite is less magnesian than the average group-I kimberlite, the existence of highly magnesian aillikites defeats distinctions based on $\mathrm{Ca} / \mathrm{Mg}$ alone (Rock, 1986). Aillikites are, however, always richer in $\mathrm{Fe}$ than kimberlites at any given $\mathrm{Mg}$ content and a $\mathrm{Fe}$ limit of $~ 11$ wt.\% $\mathrm{FeO}$ reliably separates most aillikites from kimberlites. This distinction may well be somewhat arbitrary, however, as there is commonly disagreement about whether magnesian aillikites are, or are not, group-I kimberlites.
Although both aillikites and group-I kimberlites must involve melting in carbonate-bearing systems, experimental data suggest that at the point at which group-I kimberlite liquids are produced, carbonate itself should be exhausted in the source (Moore and Wood, 1998). Classical South African group-I kimberlites have very low $\mathrm{Fe}$ contents, compatible in terms of Fe$\mathrm{Mg}$ partitioning with the refractory garnet harzburgites they host, and with which they compositionally overlap in the area of primitive mantle (Fig. 4). The more Ferich aillikites, on the other hand, require a mantle source that is significantly more Fe-rich than that of group-I kimberlites, or primitive mantle itself.

The contrast between aillikites and group-I kimberlites in terms of the behaviour of $\mathrm{Si}$ and $\mathrm{Ca}$ with decreasing $\mathrm{Mg}$ is particularly intriguing. Decreasing $\mathrm{Mg}$ is a proxy for decreasing temperature, and thus the increase in $\mathrm{Ca}$ and decrease in $\mathrm{Si}$ with decreasing $\mathrm{Mg}$ in the group-I kimberlites can be explained in terms of olivine fractionation and/or wall rock reactions of the type:

$$
\mathrm{Dol}_{\text {liq }}+\mathrm{Opx}_{\mathrm{sol}} \longrightarrow(\mathrm{Oliv}+\mathrm{Cpx})_{\mathrm{sol}}+\mathrm{Cal}_{\mathrm{liq}}+\mathrm{CO}_{2}
$$

as kimberlite magmas rise through the mantle. There is, however, no silicate phase, nor any wall rock reaction, that can increase $\mathrm{Si}$ in the aillikites with decreasing $\mathrm{Mg}$. The apparent increase in $\mathrm{Si}$ with decreasing $\mathrm{Mg}$ in the aillikites could be produced by the fractionation of olivine and dolomite; however, the few relevant experimental data that exist suggest that dolomite is unlikely to be a near liquidus phase. The aillikite trend might, however, reflect the separation of an immiscible dolomitic liquid. Perhaps the higher $\mathrm{Fe}$ content of aillikites leads to carbonate saturation and the fractionation of an immiscible dolomite melt as aillikites cool down the silicate - carbonate solvus.

Group-II kimberlites and olivine lamproites appear to constitute a compositional continuum suggesting a genetic kinship involving the fractionation of olivine, phlogopite, and clinopyroxene; in agreement with their common trace element and isotopic characteristics. Like group-I kimberlites, group-II kimberlites and olivine lamproites have low Fe contents, consistent with equilibration with a refractory mantle residue similar to the garnet harzburgite xenoliths they host (Fig. 3). Although the higher K contents of group-II kimberlites and olivine lamproites indicate derivation from a phlogopite-bearing source, experimental data indicate that the phlogopite would have been exhausted in the source at the point at which they were produced. In contrast, the meimechites are poor in $\mathrm{K}$ and rich in $\mathrm{Fe}$, and require more Fe-rich mantle sources similar to those of the aillikites. Their evolution appears to be 
controlled largely by olivine, as they grade to Fe-rich picrites with decreasing $\mathrm{Mg}$.

Both meimechites and aillikites are too Fe-rich to be produced by the partial melting of primitive mantle. These Fe-rich magmas require the existence of a largely unseen Fe-rich component in the mantle. The fact the range in $\mathrm{Fe}$ from group-II kimberlites to aillikites exactly encompasses the range in $\mathrm{Fe}$ observed in primitive terrestrial lavas suggests the possibility that this Fe-rich component may well be occult in Archean ferropicrites, as well as more recent hot-spot or 'OIB'type suites in general (Fig.4).

The results of this comparison indicate that the major element compositions of hypabyssal-facies ultramafic dykes not only provide simple criteria for their subdivision, but also valuable insights into their petrogenesis. $\mathrm{Si}$ provides an effective means for distinguishing between group-I and group-II kimberlites, whereas $\mathrm{Fe}$ distinguishes them from aillikites and meimechites respectively. The contrasting trends in group-I kimberlites versus aillikites emphasizes the importance of $\mathrm{CO}_{2}$ analyses for an understanding of their petrolgenesis. Finally, in addition to being useful for the simple classification of ultramafic dykes, the major elements have recently been shown to correlate with diamond grade in the Yakutian kimberlites (Fig. 6) (Vasilenko, et al., 2002).

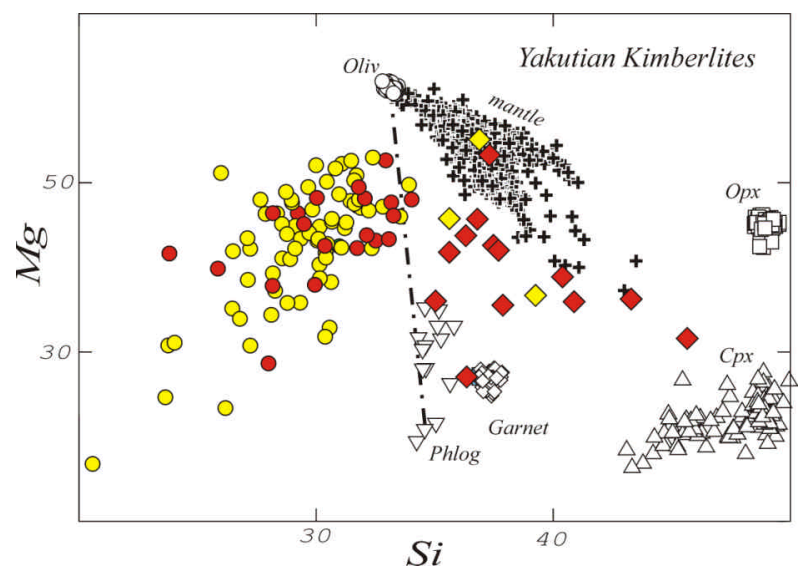

Figure 5: $\mathrm{Si}$ versus $\mathrm{Mg}$ in cation units, with group-I (circle) and group-II (diamond) Yakutian kimberlites. Red indicates those with diamond grades $>15 \mathrm{Ct} / / 10 \mathrm{t}$, those with less are in yellow. Data source: (Vasilenko, et al., 2002).

It is apparent that both group-I and group-II kimberlites are present in the Vasilenko et al. dataset and that both groups contain diamond-rich pipes. Although group-II kimberlites as a whole appear to be diamond rich, there is a general anti-correlation between diamond grade and $\mathrm{Ti}$ content (Fig. 6) in both group-I and group-II kimberlites, which might be useful in preliminary target assessments. Hopefully such results will encourage future detailed studies of the correlation between kimberlite composition and diamond potential.

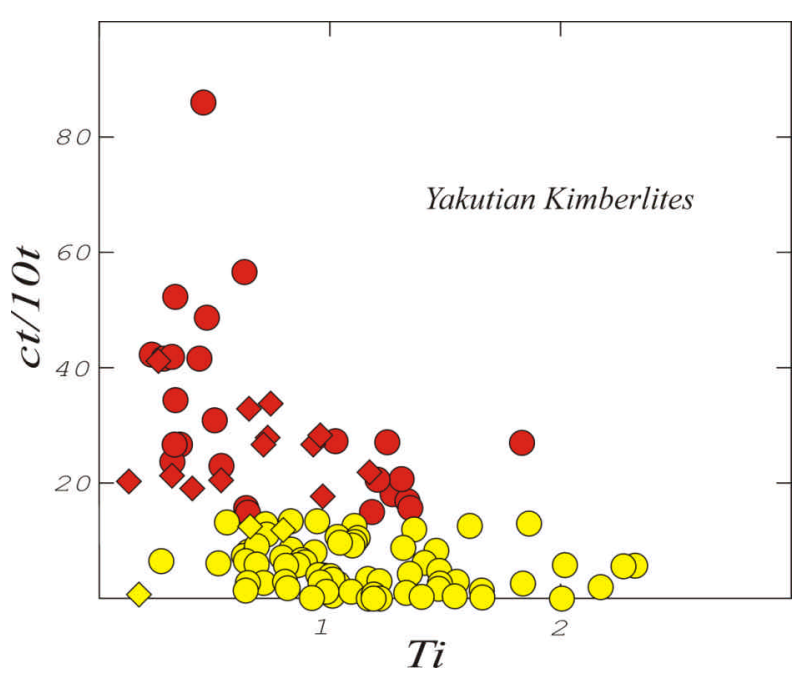

Figure 6: Ti versus carats / 10 tons for Yakutian kimberlites. Symbols as in Fig. 5

\section{REFERENCES}

Anderson, D., 1989. Theory of the Earth. Blackwell Scientific. $366 \mathrm{p}$.

Arndt, N., K. Lehneret and Y. Vasil'ev, 1995. Meimechites: highly magnesian lithopsheric-contaminated alkaline magmas from the deep subcontinental mantle. Lithos 34, 41-59.

Baragar, W. R., U. Mader and G. M. Lecheminant, 2001. Paleoproterozoic carbonatitic ultrabasic volcanic rocks (meimechites?) of Cape Smith Belt, Quebec. Can. J. Earth Sci. 38, 1313-1325.

Bourne, J. H. and J. Bossé, 1991. Geochemistry of ultramafic and calc-alkaline lamprophyres from the Lac Shortt area, Quebec. Mineral. Petrol. 45, 85-193.

Digonnet, S., N. Goulet, J. Bourne, R. Stevenson and D. Archibald, 2000. Petrology of the Abloviak aillikite dykes, New Québec: evidence for a Cambrian 
diamondiferous alkaline province in northeastern North America. Can. J. Earth Sci.37, 517-533

Edwards, D., N. M. S. Rock, W. R. Taylor, B. J. Griffin and R. R. Ramsay, 1992. Mineralogy and Petrology of the Aries diamondiferous kimberlite pipe, central Kimberley Block, Western Australia. J. Petrology 33, 1157-1191.

Francis, D., 1995. Implications of picritic lavas for the mantle sources of terrestrial volcanism. Lithos 34, 89-105.

Fraser, K. J. and C. J. Hawkesworth, 1992. The petrogenesis of group 2 ultrapotassic kimberlites from Finsch Mine, South Africa. Lithos 28, 327-345.

Jaques, A. L., J. D. Lewis, C. B. Smith, G. P. Gregory, J. Ferguson, B. W. Chapell and M. T. McCulloch, 1984. The diamond-bearing ultrapotassic (lamproitic) rocks of the West Kimberley region, western Australia Proceedings of the Third International Kimberlite Conference 1, 225-254.

Larsen, L. M. and D. C. Rex, 1992. A review of $2500 \mathrm{Ma}$ span of alkaline-ultramafic, potassic and carbonatitic magmatism in West Greenland. Lithos 28, 367-402.

LeRoex, D. R. Bell and P. Davis, 2003. Petrogenesis of Group-I kimberlites from Kimberley, South Africa: evidence from bulk rock geochemistry. J. Petrology, in press.

Moore, K. R. and B. J. Wood, 1998. The transition from carbonatite to silicate melts in the $\mathrm{CaO}$ $\mathrm{MgO}-\mathrm{SiO}_{2}-\mathrm{CO}_{2}$ system. J. Petrology 39, 1943-1951.

Price, s. E., J. K. Russell and M. G. Kopylova, 2000. Primitive magma from the Jericho Pipe, N.W.T., Canada: constraints on primary kimberlite melt chemistry. J. Petrology 41, 789-808.

Rock, N. M. S., 1986. The nature and origin of ultramafic lamprophyres: alnoites and allied rocks. J. Petrology 27, 155-196.

Schmidberger, S. S. and D. Francis, 2001. Constraints on the trace element composition of the late Archean mantle root beneath Somerset Island, Arctic Canada. J. Petrology, in press,

Scott, B. H., 1979. Petrogenesis of kimberlites and associated potassic lamprophyres from central west Greenland.
Proceedings of the Second International Kimberlite Conference 2, 190-205.

Scott Smith, B. H., L. J.P. and H. R. Robison, 1996. Geology of the Sturgeon Lake 01 kimberlite block, Saskatchewan. Expl. Mining Geol. 5, 251-261.

Taylor, W. R., T. L.A. and S. E. Haggerty, 1994. Comparative geochemistry of West African kimberlites: Evidence for a micaceous kimberlite end member of sublithospheric origin. Geochim. Cosmochim. Acta 58, 4017-4037.

Vasilenko, V. B., N. N. Zinchuk, V. O. Krasavchikov, L. G. Kuznetsova, V. V. Khlestov and N. I. Volkova, 2002. Diamond potential estimation based on kimberlite major element chemistry. J. Geochem. Expl. 79, 93112.

Yoder, H. S., 1986. Potassium-rich rocks: phase analysis and heteromorphic reactions J. Petrology 27, 1215-1228.

Contact: D Francis, rm. 238, 3450 University St. Montréal, Québec, Canada H3A 2A7 